Dept. of Food Control,

Fac. of Vet. Med., Zagazig University, Egypt.

\title{
EVALUATION OF HYGIENIC QUALITY OF LARGE SCALE MANUFACTURED YOGHURT SOLD IN SHARKIA GOVERNORATE \\ (With 14 Tables)
}

By

\author{
NESMA I.S. YASEN; S.F.A. ABD EL AAL; \\ M.A.H. MANSOUR and I.H. AMER
}

(Received at 1/3/2011)

تقييم الحالة الصحية للزبادي المصنع على في نطاق واسع والمباع

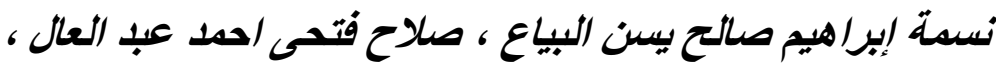

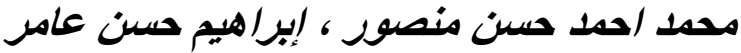

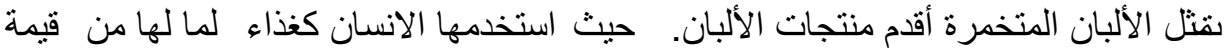

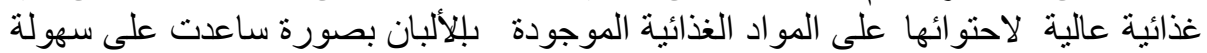

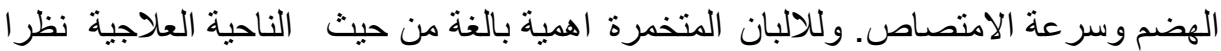

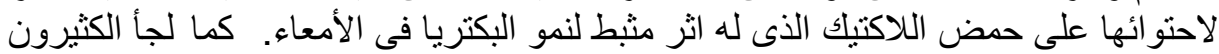

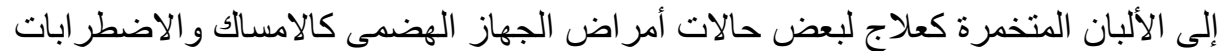

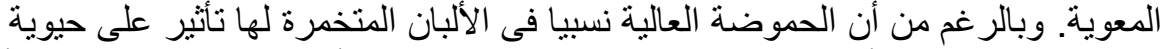

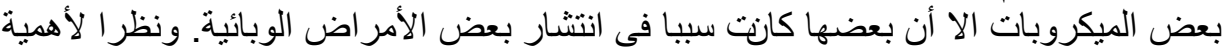

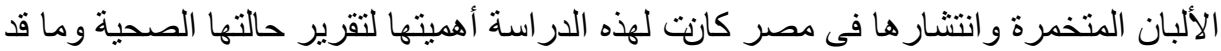

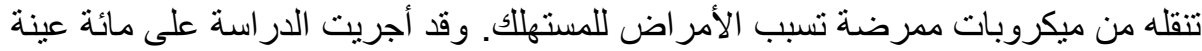

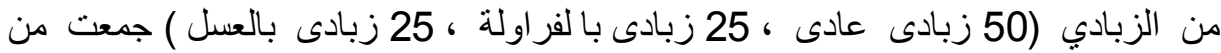

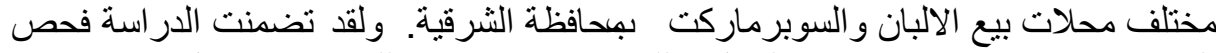

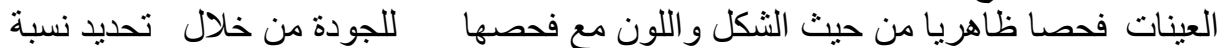

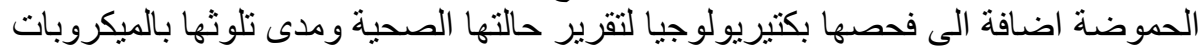

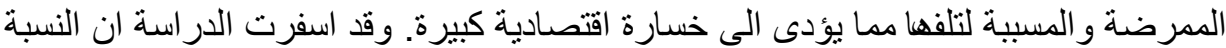

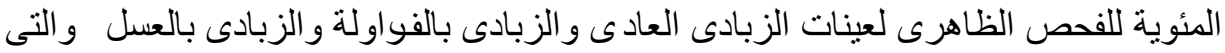

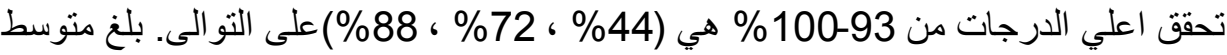

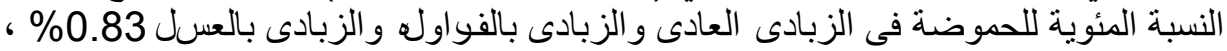

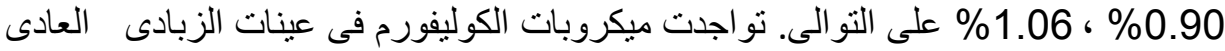

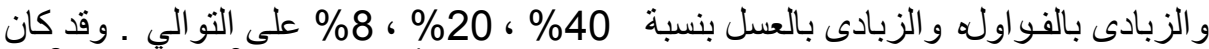

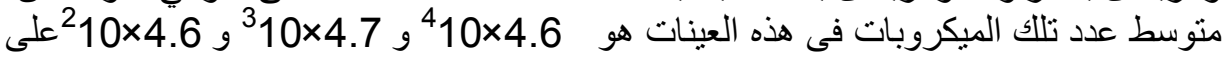


التو الي. تم عزل وتصنيف عتر ات ستروباكتر فرينداى وانتيروباكتر اجلومير انز وكليبسيلا

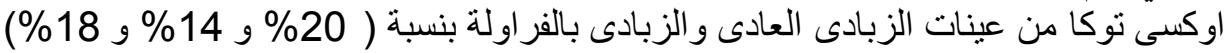

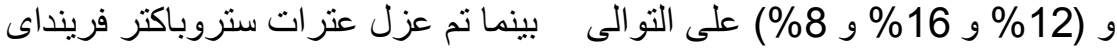

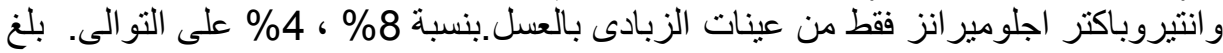

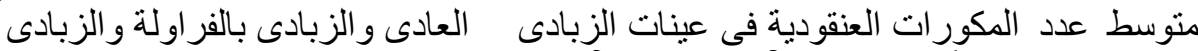

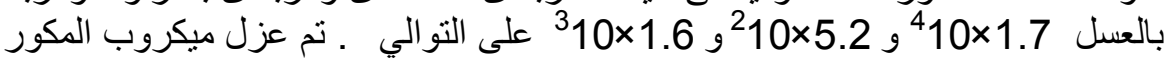

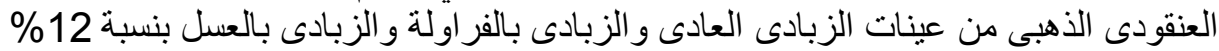

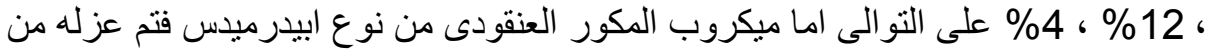

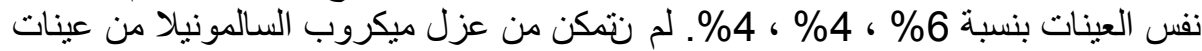

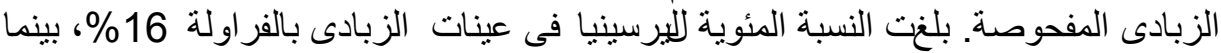

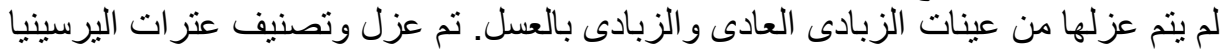

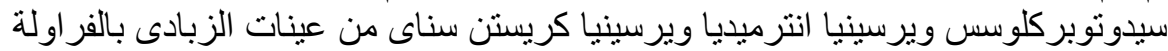

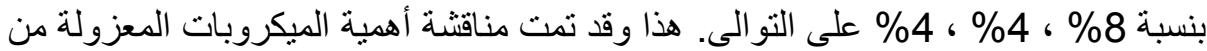

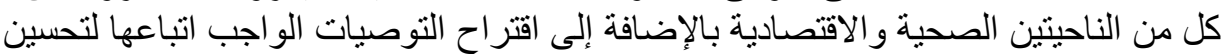
جودة الألبان الزبادى للحفاظ على صحة المستهلك من الأخطار الصحية.

\section{SUMMARY}

hundred random samples, fifty of natural yoghurt (plain) and 25 each of fruit yoghurt (strawberry) and flavored yoghurt (honey) were collected from different dairy shops and markets in Sharkia Governorate, Egypt. The collected samples were examined physically (sensory evaluation), sanitary (determination of titratable acidity), and bacteriologically. The obtained results revealed that the highest frequency distribution of examined yoghurt samples based on suggested score for sensory evaluation was $44 \%$ of examined natural yoghurt samples and lies within the range of $93-100 \%$, while $72 \%$ of the examined fruit yoghurt samples and $88 \%$ of examined flavored yoghurt lie within the same range. Acidity\% in natural and fruit yoghurt samples was $0.83 \%$ and $0.90 \%$, respectively, while in case of flavored yoghurt samples was $1.06 \%$. The mean coliform count/g in examined yoghurt samples was $4.6 \times 10^{4}$ and $4.7 \times 10^{3}$ for natural and fruit yoghurt, respectively while, coliform organisms in examined flavored yoghurt were $4.6 \times 10^{2} / \mathrm{g}$. The most prevalent coliform species isolated from examined natural and fruit yoghurt samples were Citrobacter freundii, Enterobacter agglomerans and $K$. oxytoca in percentages of $(20 \%, 14 \%$ and $18 \%)$ and $(12 \%, 16 \%$ and $8 \%$ ), respectively, while in the examined flavored yoghurt samples the most prevalent coliform species were Citrobacter freundii and Enterobacter agglomerans in percentages of $8 \%$ and $4 \%$, respectively. The mean staphylococci count/g in examined natural and fruit yoghurt was $1.7 \times 10^{4}$ and $5.2 \times 10^{2}$, respectively but in case of flavored yoghurt it 
was $1.6 \times 10^{3}$. Staphylococcus aureus and Staph. epidermidis were the predominated staphylococci isolated from the examined natural, fruit and flavored yoghurt samples in percentages of (12\% and 6\%), (12\% and $4 \%$ ) and (4\% and 4\%), respectively. Salmonellae failed to be detected in examined samples. Yersinia spp. could be detected in $16 \%$ out of examined fruit yoghurt samples while they couldn't be detected in both examined natural and flavored yoghurt samples. Yersinia pseudotuberculosis, $Y$. intermedia and $Y$. kristensenii could be isolated from the fruit yoghurt samples in percentages of $8 \%, 4 \%$ and $4 \%$, respectively. The sanitary and public health importance of isolated microorganisms as well as their control measures were discussed to improve the quality of yoghurt and to safe guard the consumers from infection.

Key words: Hygienic quality, yoghurt, coliforms, staphylococci, yersinia spp., salmonellae.

\section{INTRODUCTION}

Milk and milk products are universally recognized as first class food stuff due to their exceptional richness in high quality animal protein, milk fat, high content of calcium, phosphorous and performed vitamin A and B2. The outstanding nutritive value of these products makes them indispensable in human nutrition. Moreover, such products are good supplement for a deficient diet at all times.

Many claims may be made for the therapeutic value of fermented milk in the diet of people. Ancient physicians prescribed sour milk for dysentery, tuberculosis, liver complaints and inflammation of intestinal tract a host of other maladies. Even though most of the claims for therapeutic value of fermented milks are grossly exaggerated, physicians today prescribe acidophilus milk in the diet of some persons affected with constipation or diarrhoea. In fact, researches have recently proved that antibiotics could be produced by organisms used in milk fermentation as acidophilin, lactocidin, lactoline, nicin and diplococcin. Such antibiotics may inhibit the growth of several food-borne pathogens (Steven, 1969; Goel et al., 1971; Shahani et al., 1974; Abou-Donia et al., 1975).

Natural or plain yoghurt was the traditional type of fermented milks with a sharp acidic taste, while fruit yoghurt was made by the addition of fruits and sweeting agents to natural yoghurt (Potter and Hotchkiss, 1995). Fruit yoghurt usually have incorporated stabilizers to reduce whey separation during distribution and many of the stabilizers 
are complex carbohydrates which providing "a bulking agent "for stimulating intestinal peristalsis and avoiding some the risk of colonic malfunction. It also absorbs some of the potentially toxic chemicals that may be formed in the large intestine as a result of bacterial action. These unavailable carbohydrates are acting to further delay the diffusion of sugar to the intestinal wall that could help lactose intolerant patients and those prone to post prandial hyperglycemia. (Robinson and Khan, 1978 and Tamime and Robinson, 1985).

Contaminations of milk with coliforms with special reference to faecal coliforms give an indication of either direct or indirect faecal contamination and considered as a mirror for the degree of disregard of numerous hygienic rules during milking (ICMSF, 1986 and Varnam and Evans, 1991). Coliform also appear to be capable of colonizing in the human gut and producing potent enterotoxins in high yield. During the last few years, strains of Klebsilla, Enterobacter and Citrobacter have been isolated from stools or the intestinal tract of children and adults in several epidemiological studies of acute and chronic diarrheal diseases (Robert and Brenda, 1979).

The presence of coagulase positive, Staphylococcus aureus in a food gave an indication about its contamination from skin, mouth or handling, but inadequately cleaned utensils or equipment may be also a source of contamination. (Newsome, 1988). Staphylococcus aureus possess a public health hazard due to production of thermostable enterotoxins that was responsible for food-poisoning. (Wernozy-Rozand et al., 1996).

Salmonellae are world wide and universally recognized as zoonotic agents. Numerous animal reservoirs have been identified, many foods, particularly of animal origin and those subjected to sewage pollution, have been identified as vehicle for transmitting these pathogens to human being (Robert et al., 1996).

Yersinia enterocolitica is one of the human pathogenic species of Yersinia and of major importance in view of food hygiene. Raw milk and milk products have been shown to be a vector of infections in a number of Yersinia enterocolitica related food-borne outbreaks. (Moustafa et al., 1983; Odinot et al., 1995). Yersinia enterocolitica has been isolated from many animal species, with most isolates being virulent strains for humans. Exception was swine; they were principle resevior for virulent strains, which were often isolated from oral cavity (tounge and tonsils) of apparently healthy animals. (Anonymous, 1977; Tacket et al., 1984). 
In recognition of public health and economic significance of these microorganisms, therefore, the present study was done to investigate the examined yoghurt samples physically, sanitary and bacteriology as well as assessment of the economic and public health significance of isolated microorganisms in relation to yoghurt.

\section{MATERIALS and METHODS}

\section{Collection of samples:}

One hundred random samples, fifty of natural yoghurt (plain) and 25 each of fruit yoghurt (strawberry) and flavored yoghurt (honey) were collected in their retail packages from different dairy shops and markets in Sharkia Governorate. Collected samples were transferred directly to the laboratory in an insulated ice-box at $4{ }^{\circ} \mathrm{C}$ with a minimum of delay to be examined physically, sanitary and bacteriologically.

\section{Preparation of the Samples:}

On arrival to the laboratory each sample was perfectly mixed and examined physically (sensory evaluation) before being divided into two parts. The first one used for sanitary examination (determination of titratable acidity), while the second one was examined bacteriologically.

\section{A- Physical examination:}

Sensory evaluation (Sangwan, 2008): Yoghurt samples were examined for physical properties then graded according to the scores.

Table 1: Sensory evaluation of yoghurt samples.

\begin{tabular}{|l|c|}
\hline \multicolumn{1}{|c|}{ Attribute } & Maximum score \\
\hline Flavor & 45 \\
Body and Texture & 30 \\
Appearance & 10 \\
Sediment & 10 \\
Container & 5 \\
\hline Total & 100 \\
\hline
\end{tabular}

Table 2: Suggested scores for a defective yoghurt samples. 
Assiut Vet. Med. J. Vol. 57 No. 129 April 2011

\begin{tabular}{|c|c|c|c|c|}
\hline \multirow[t]{2}{*}{ Attribute } & \multirow[t]{2}{*}{ Defect } & \multicolumn{3}{|c|}{ Degree of defect } \\
\hline & & Slight & Moderate & Pronounced \\
\hline \multirow[t]{7}{*}{ Flavor } & Bitter & $38-40$ & $35-37$ & $32-34$ \\
\hline & Cheesy & $38-40$ & $35-37$ & $32-34$ \\
\hline & Flat & $40-42$ & $37-39$ & $34-36$ \\
\hline & Low-acid & $40-42$ & $37-39$ & $34-36$ \\
\hline & High-acid & $40-42$ & $37-39$ & $34-36$ \\
\hline & Yeasty & $38-40$ & $35-37$ & $32-34$ \\
\hline & Foreign & $38-40$ & $35-37$ & $32-34$ \\
\hline \multirow[t]{6}{*}{ Body and Texture } & Curdy & $26-27$ & $23-26$ & $21-22$ \\
\hline & Gassly & $26-27$ & $23-26$ & $21-22$ \\
\hline & Lumpy & $27-28$ & $24-26$ & $21-22$ \\
\hline & Ropy & $27-28$ & $24-26$ & $22-23$ \\
\hline & Thin & $27-28$ & $24-26$ & $22-23$ \\
\hline & Wheyed off & $27-27$ & $24-26$ & $22-23$ \\
\hline Sediment & Chalky,dull & 9 & 7 & 5 \\
\hline Appearance & Unsighty, & 9 & 8 & 7 \\
\hline Container & Soiled & 4 & 3 & 2 \\
\hline
\end{tabular}

\section{B-Sanitary examination:}

Determination of titratable acidity percentage by using standard method (A.P.H.A., 1992).

\section{C-Bacteriological examination:}

1- Preparation of serial dilutions (A.P.H.A., 1992).

2- Enumeration and isolation of coliforms (MPN/gm); (A.P.H.A., 1992). Identification of the isolated coliform organisms (Krieg and Holt, 1984).

3- Enumeration and isolation of staphylococci (A.P.H.A., 1992).

Identification of the isolated Staphylococcus organisms (Cowan and Steel, 1974).

4- Isolation of Salmonella spp. (A.P.H.A., 1992).

5- Isolation of Yersinia spp. (A.P.H.A., 1992).

Identification of the isolated Yersinia spp. (FDA, 1998).

\section{RESULTS}


Table 3: Frequency distribution of the examined yoghurt samples based on their sensory evaluation.

\begin{tabular}{|c|c|c|c|c|c|c|c|}
\hline \multirow{2}{*}{$\begin{array}{c}\text { Degree of } \\
\text { defect }\end{array}$} & $\begin{array}{c}\text { Suggested } \\
\text { Scores }\end{array}$ & \multicolumn{2}{|c|}{$\begin{array}{c}\text { Natural yoghurt } \\
\text { (Plain) } \\
(\mathrm{n}=50)\end{array}$} & \multicolumn{2}{c|}{$\begin{array}{c}\text { Fruit yoghurt } \\
\text { (Strawberry) } \\
(\mathrm{n}=25)\end{array}$} & $\begin{array}{c}\text { Flavored yoghurt } \\
\text { (Honey) } \\
(\mathrm{n}=25)\end{array}$ \\
\cline { 3 - 8 } & No. & $\%$ & No. & $\%$ & No. & $\%$ \\
\hline No defect & $93-100$ & 22 & 44.0 & 18 & 72.0 & 22 & 88.0 \\
\hline Slight & $86-92$ & 12 & 24.0 & 4 & 16.0 & 2 & 8.0 \\
\hline Moderate & $76-83$ & 7 & 14.0 & 2 & 8.0 & 1 & 4.0 \\
\hline Pronounced & $67-73$ & 9 & 18.0 & 1 & 4.0 & 0 & 0.0 \\
\hline & Total & 50 & 100.0 & 25 & 100.0 & 25 & 100.0 \\
\hline
\end{tabular}

$\mathrm{n}$ : means the number of examined samples

Table 4: Statistical analytical results of titratable acidity $\%$ in the examined yoghurt samples.

\begin{tabular}{|c|c|c|c|c|}
\hline Type of samples & Minimum & Maximum & Mean & \pm S.E.M \\
\hline $\begin{array}{c}\text { Natural yoghurt } \\
\text { (Plain) }(\mathrm{n}=50)\end{array}$ & 0.66 & 1.12 & 0.83 & 0.012 \\
\hline $\begin{array}{c}\text { Fruit yoghurt (Strawberry) } \\
(\mathrm{n}=25)\end{array}$ & 0.73 & 1.24 & 0.90 & 0.021 \\
\hline $\begin{array}{c}\text { Flavored yoghurt } \\
\text { (Honey) }(\mathrm{n}=25)\end{array}$ & 0.99 & 1.32 & 1.06 & 0.017 \\
\hline
\end{tabular}

Table 5: Frequency distribution of the examined yoghurt samples based on their titratable acidity $\%$.

\begin{tabular}{|c|c|c|c|c|c|c|}
\hline Type of samples & \multicolumn{2}{|c|}{$\begin{array}{c}\text { Natural yoghurt } \\
\text { (Plain) } \\
\text { Intervals }\end{array}$} & \multicolumn{2}{|c|}{$\begin{array}{c}\text { Fruit yoghurt } \\
\text { (Strawberry) } \\
(\mathrm{n}=25)\end{array}$} & \multicolumn{2}{c|}{$\begin{array}{c}\text { Flavored yoghurt } \\
\text { (Honey) } \\
(\mathrm{n}=25)\end{array}$} \\
\cline { 2 - 7 } & No. & $\%$ & No. & $\%$ & No. & $\%$ \\
\hline $0.60-0.70$ & 9 & 18.0 & 0 & 0.0 & 0 & 0.0 \\
\hline $0.71-0.80$ & 18 & 36.0 & 5 & 20.0 & 0 & 0.0 \\
\hline $0.81-0.90$ & 14 & 28.0 & 13 & 52.0 & 0 & 0.0 \\
\hline $0.91-1.00$ & 6 & 12.0 & 2 & 8.0 & 18 & 72.0 \\
\hline $1.01-1.10$ & 2 & 4.0 & 2 & 8.0 & 3 & 12.0 \\
\hline $1.11-1.20$ & 1 & 2.0 & 0 & 0.0 & 2 & 8.0 \\
\hline $1.21-1.30$ & 0 & 0.0 & 3 & 12.0 & 1 & 4.0 \\
\hline $1.31-1.40$ & 0 & 0.0 & 0 & 0.0 & 1 & 4.0 \\
\hline Total & 50 & 100.0 & 25 & 100.0 & 25 & 100.0 \\
\hline
\end{tabular}


Table 6: Statistical analytical results of coliform count/g. in the examined yoghurt samples (MPN/g).

\begin{tabular}{|c|c|c|c|c|c|c|}
\hline \multirow{2}{*}{ Type of samples } & \multirow{2}{*}{$\begin{array}{c}\text { No. of } \\
\text { examined } \\
\text { samples }\end{array}$} & \multicolumn{2}{|c|}{$\begin{array}{c}\text { Positive } \\
\text { samples }\end{array}$} & \multicolumn{3}{|c|}{ Count/g. } \\
\cline { 4 - 7 } & & No. & $\%$ & Min. & Max. & Mean \\
\hline $\begin{array}{c}\text { Natural Yoghurt } \\
\text { (Plain) }\end{array}$ & 50 & 20 & 40.0 & $\begin{array}{c}3.0 \\
\text { X10 }\end{array}$ & $7.0 \times 10^{5}$ & $4.6 \times 10^{4}$ \\
\hline $\begin{array}{c}\text { Fruit Yoghurt } \\
\text { (Straw berry) }\end{array}$ & 25 & 5 & 20.0 & $8.0 \times 10^{2}$ & $6.0 \times 10^{4}$ & $4.7 \times 10^{3}$ \\
\hline $\begin{array}{c}\text { Flavored Yoghurt } \\
\text { (Honey) }\end{array}$ & 25 & 2 & 8.0 & $2.0 \times 10^{2}$ & $9.0 \times 10^{3}$ & $4.6 \times 10^{2}$ \\
\hline
\end{tabular}

Table 7: Frequency distribution of the examined yoghurt samples based on their coliform count/g.

\begin{tabular}{|c|c|c|c|c|c|c|}
\hline \multirow{2}{*}{ Type of samples } & \multicolumn{2}{|c|}{$\begin{array}{c}\text { Natural yoghurt } \\
\text { (Plain) } \\
\text { Intervals }\end{array}$} & \multicolumn{2}{|c|}{$\begin{array}{c}\text { Fruit yoghurt } \\
\text { (ntrawberry) } \\
(\mathrm{n}=25)\end{array}$} & \multicolumn{2}{c|}{$\begin{array}{c}\text { Flavored yoghurt } \\
\text { (Honey) } \\
(\mathrm{n}=25)\end{array}$} \\
\cline { 2 - 7 } & No. & $\%$ & No. & $\%$ & No. & $\%$ \\
\hline $10^{2-}$ & 13 & 65.0 & 4 & 80.0 & 1 & 50.0 \\
\hline $10^{3}-$ & 4 & 20.0 & 0 & 0.0 & 1 & 50.0 \\
\hline $10^{4}-$ & 1 & 5.0 & 1 & 20.0 & 0 & 0.0 \\
\hline $10^{5}-$ & 2 & 10.0 & 0 & 0.0 & 0 & 0.0 \\
\hline Total & 20 & 100.0 & 5 & 100.0 & 2 & 100.0 \\
\hline
\end{tabular}

Table 8: Incidence of isolated coliforms in the examined yoghurt samples.

\begin{tabular}{|l|c|c|c|c|c|c|}
\hline \multicolumn{1}{|c|}{ Type of samples } & \multicolumn{2}{|c|}{$\begin{array}{c}\text { Natural yoghurt } \\
\text { (Plain) } \\
(\mathrm{n}=50)\end{array}$} & \multicolumn{2}{c|}{$\begin{array}{c}\text { Fruit yoghurt } \\
\text { Strawberry) } \\
(\mathrm{n}=25)\end{array}$} & \multicolumn{2}{c|}{$\begin{array}{c}\text { Flavored yoghurt } \\
\text { (Honey) } \\
(\mathrm{n}=25)\end{array}$} \\
\cline { 2 - 8 } Isolated organisms & No. & $\%$ & No. & $\%$ & \multicolumn{2}{c|}{$\begin{array}{c}\text { No. } \\
\%\end{array}$} \\
\hline Citrobacter freundii & 10 & 20.0 & 3 & 12.0 & 2 & 8.0 \\
\hline $\begin{array}{l}\text { Enterobacter } \\
\text { agglomerans }\end{array}$ & 7 & 14.0 & 4 & 16.0 & 1 & 4.0 \\
\hline Klebsiella oxytoca & 9 & 18.0 & 2 & 8.0 & 0 & 0.0 \\
\hline
\end{tabular}


Table 9: Statistical analytical results of staphylococci count/g. in the examined yoghurt samples.

\begin{tabular}{|c|c|c|c|c|c|c|}
\hline \multirow{2}{*}{ Type of samples } & \multirow{2}{*}{$\begin{array}{c}\text { No. of } \\
\text { examined } \\
\text { samples }\end{array}$} & \multicolumn{2}{|c|}{$\begin{array}{c}\text { Positive } \\
\text { samples }\end{array}$} & \multicolumn{3}{|c|}{ Count/g. } \\
\cline { 3 - 7 } & No. & $\%$ & Min. & Max. & Mean \\
\hline $\begin{array}{c}\text { Natural yoghurt } \\
\text { (plain) }\end{array}$ & 50 & 9 & 18 & $2.0 \times 10^{2}$ & $4.0 \times 10^{5}$ & $1.7 \times 10^{4}$ \\
\hline $\begin{array}{c}\text { Fruit yoghurt } \\
\text { (Straw berry) }\end{array}$ & 25 & 4 & 16 & $4.0 \times 10^{2}$ & $7.0 \times 10^{3}$ & $5.2 \times 10^{2}$ \\
\hline $\begin{array}{c}\text { Flavored yoghurt } \\
\text { (Honey) }\end{array}$ & 25 & 2 & 8 & $2.0 \times 10^{2}$ & $3.0 \times 10^{3}$ & $1.6 \times 10^{3}$ \\
\hline
\end{tabular}

Table 10: Coagulase production of the isolated staphylococci strain in examined yoghurt samples.

\begin{tabular}{|c|c|c|c|c|c|c|}
\hline & \multicolumn{2}{|c|}{$\begin{array}{c}\text { Natural yoghurt } \\
\text { (Plain) } \\
(\mathrm{n}=50)\end{array}$} & \multicolumn{2}{c|}{$\begin{array}{c}\text { Fruit yoghurt } \\
\text { (Strawberry) } \\
(\mathrm{n}=25)\end{array}$} & \multicolumn{2}{c|}{$\begin{array}{c}\text { Flavored } \\
\text { yoghurt } \\
\text { (Honey) } \\
(\mathrm{n}=25)\end{array}$} \\
\hline & No. & $\%$ & No. & $\%$ & No. & $\%$ \\
\hline+++ & 6 & 12.0 & 3 & 12.0 & 1 & 4.0 \\
\hline++ & 2 & 4.0 & 1 & 4.0 & 0 & 0.0 \\
\hline+ & 1 & 2.0 & 0 & 0.0 & 1 & 4.0 \\
\hline
\end{tabular}

+++ means strong positive coagulase

++ means positive coagulase

+ means weekly positive coagulase

Table 11: Incidence of the isolated staphylococci in the examined yoghurt samples.

\begin{tabular}{|l|c|c|c|c|c|c|}
\hline \multicolumn{1}{|c|}{ Type of samples } & \multicolumn{2}{|c|}{$\begin{array}{c}\text { Natural yoghurt } \\
\text { (Plain) } \\
\text { In=50) }\end{array}$} & $\begin{array}{c}\text { Fruit yoghurt } \\
\text { (Straw berry) } \\
(\mathrm{n}=25)\end{array}$ & $\begin{array}{c}\text { Flavored } \\
\text { yoghurt } \\
\text { (Honey) } \\
(\mathrm{n}=25)\end{array}$ \\
\cline { 2 - 7 } & No. & $\%$ & No. & $\%$ & No. & $\%$ \\
\hline Staphylococcus aureus & 6 & 12.0 & 3 & 12.0 & 1 & 4.0 \\
\hline Staphylococcus epidermidis & 3 & 6.0 & 1 & 4.0 & 1 & 4.0 \\
\hline
\end{tabular}


Table 12: Incidence of Yersinia spp. in the examined yoghurt samples.

\begin{tabular}{|c|c|c|c|}
\hline product & $\begin{array}{c}\text { No. of examined } \\
\text { samples }\end{array}$ & \multicolumn{2}{|c|}{ Positive samples } \\
\cline { 3 - 4 } & 50 & 0 & 0.0 \\
\hline Natural yoghurt (Plain) & 25 & 4 & 16.0 \\
\hline Fruit yoghurt (Strawberry) & 25 & 0 & 0.0 \\
\hline Flavored yoghurt (Honey) & 100 & 4 & 4.0 \\
\hline Total & & & \\
\hline
\end{tabular}

Table 13: Incidence of different types of Yersinia spp. in the examined fruit yoghurt samples.

\begin{tabular}{|l|c|c|}
\hline \multicolumn{1}{|c|}{ Type of samples } & \multicolumn{2}{|c|}{$\begin{array}{c}\text { Fruit yoghurt } \\
\text { (Straw berry) } \\
\text { In=25) }\end{array}$} \\
\cline { 2 - 3 } Isolated organisms & No. & $\%$ \\
\hline Yersinia pseudo tuberculosis & 2 & 4.0 \\
\hline Yersinia intermedia & 1 & 4.0 \\
\hline Yersinia kristensenii & 1 & \\
\hline
\end{tabular}

Table 14: Correlation between titratable acidity, coliforms, staphylococci and Yersinia spp. in the examined yoghurt samples.

\begin{tabular}{|c|c|c|c|c|}
\hline Type of samples & Organisms & $\begin{array}{c}\text { Pearson correlation } \\
\text { between isolated } \\
\text { M.Os and acidity }\end{array}$ & $\begin{array}{c}\text { Sig. } \\
\text { (2-tailed) }\end{array}$ & Sig. \\
\hline $\begin{array}{c}\text { Natural yoghurt } \\
\text { (plain) } \\
(\mathrm{n}=50)\end{array}$ & Coliforms & $0.240-$ & 0.094 & N.S. \\
\cline { 2 - 5 } & Staphylococci & $0.155-$ & 0.284 & N.S. \\
\hline $\begin{array}{c}\text { Fruit yoghurt } \\
\left(\begin{array}{c}\text { Straw berry) } \\
(\mathrm{n}=25)\end{array}\right.\end{array}$ & Coliforms & 0.330 & 0.107 & N.S. \\
\cline { 2 - 5 } & Staphylococci & 0.161 & 0.441 & N.S. \\
\cline { 2 - 5 } $\begin{array}{c}\text { Flavored yoghurt } \\
(\text { Honey) } \\
(\mathrm{n}=25)\end{array}$ & Coliforms & 0.102 & 0.074 & N.S. \\
\cline { 2 - 5 } & Staphylococci & 0.570 & 0.003 & $* *$ H.S. \\
\hline
\end{tabular}

**H.S.: Highly significant $(\mathrm{P}<0.01)$

N.S.: Non significant 


\section{DISCUSSION}

Table 3 revealed that the highest frequency distribution of examined yoghurt samples based on their suggested score for sensory evaluation was $44 \%$ in examined natural yoghurt samples and lies within the range of $93-100 \%$, while it was $72 \%$ for examined fruit yoghurt samples and $88 \%$ for examined flavored yoghurt which lies within the previously mentioned range. Sensory criteria are essential parameters that constitute the "eating quality" of dairy products which cann't be easily measured either chemically or physically. All primary classic senses: sight, smell, taste, touch and sound should be used in the sensory evaluation of yoghurt. Sight is used for evaluation of many factors as style, cleanliness of package, exterior attractiveness of finished product, package closure, body and texture, color and overall appearance and quality defects. The flavor sense of yoghurt samples detects the normal and impact (defective) flavor. Quality of yoghurt samples can be described as a value related to flavor, color and texture. It also includes imperceptible traits such as aesthetic value and safety, evaluation of raw material and final products standards, the design of dairy plant, process line layout and the design storage and distribution of yoghurt. It also concerned with packaging, storage and distribution of yoghurt samples (Al-Ashmawy et al., 1991).

The results summarized in Table 4 showed that the titratable acidity $\%$ in examined natural yoghurt samples was ranged from 0.66 to $1.12 \%$ with an average of 0.83 , while in examined fruit yoghurt samples it was ranged from $0.73-1.24 \%$ with a mean value of $0.90 \pm 0.021$ and 0.99 to $1.32 \%$ with a mean value of $1.06 \pm 0.017$ for examined flavored yoghurt samples. The highest frequency distribution of examined natural yoghurt samples based on their titratable acidity \% was $36.0 \%$ which lies within the range of 0.71-0.80, while in case of fruit yoghurt samples was $52.0 \%$ and lies within the range of $0.81-0.90$ but in case of examined flavored yoghurt samples it was $72.0 \%$ and lies within the range of 0.91-1.0 (Table 5).

Nearly similar data were obtained by Ayoub (1986); Moustafa et al. (1988); Al-Ashmawy et al. (1991); Abd El-Fatah (2007), while higher values were reported by El-Shinawy (1987); Ayoub (1991)

Titratable acidity\% of yoghurt samples has a greater importance where it is used for assessing the keeping quality. Higher acidity of yoghurt samples may be attributed to contamination either by lactic acid producing microorganisms or pathogenic microorganisms which ferment 
lactose and elevate the acidity. It is rendering the yoghurt samples unmarketable due to off-taste and unfit for human consumption due to pathogens (A.P.H.A., 1992).

The therapeutic value of yoghurt is due to it's acidity which lead to inhibiting or inactivating the most pathogens such as Salmonella spp. and coliforms. The inhibition of potential pathogens is reinforced by the production of antibiotic substances produced by lactic acid-producing bacteria (Rubin 1985; Prakash and Kulkarni, 1986).

The result tabulated in Table 6 showed that the total coliform count (MPN/g.) of examined natural yoghurt was ranged from $3.0 \mathrm{x} 10^{2}$ to $7.0 \times 10^{5}$ with an average of $4.6 \times 10^{4}$, while in those of fruit type it ranged from $8.0 \times 10^{2}$ to $6.0 \times 10^{4}$ with a mean value of $4.7 \times 10^{3}$ but it ranged from $2.0 \times 10^{2}$ to $9.0 \times 10^{3}$ with a mean of $4.6 \times 10^{2}$ in case of examined flavored yoghurt samples. These finding were inagreement with those reported by Aboul-Khire et al. (1985); Saad et al. (1987); Moustafa et al. (1988); Al-Hadethi et al. (1992); El-Barbary (1999); Mansour et al. (1999); Abd El-Fatah (2007), while higher results were obtained by Ayoub (1986); Farid et al. (1992); El-Badry (1998). But lower results were recorded by Saudi et al. (1988); Al-Ashmawy et al. (1991).

The results listed in Table 7 revealed that the highest frequency distribution of examined yoghurt based on their coliform counts was $65 \%$ in examined natural yoghurt and lies within the range of $10^{2}-10^{3}$, while it was $80 \%$ and $50 \%$ in examined fruit and flavored yoghurt samples, respectively which lies within the same range.

The result reported in Table 8 showed that Citrobacter freundii, Enterobacter agglomerans and Klebsiella oxytoca could be isolated from the examined natural yoghurt samples in percentages of $20 \%, 14 \%$ and $18 \%$, respectively, while in examined fruit yoghurt samples were $12 \%$, $16 \%$ and $8 \%$, respectively. Only Citrobacter freundii and Enterobacter agglomerans were isolated from examined flavored yoghurt samples in percentages of $8 \%$ and $4 \%$.

Slightly higher findings were reported by Ayoub (1986). The result obtained by Pintor et al. (1989); El-Badry (1998); Abd El-Fatah (2007) showed that E. coli failed to be detected in examined plain and fruit yoghurt samples, but it could be isolated by Brazal Garcia et al. (1986); Ahmed (1989); Bahout and El-Shawaf (1999).

It s evident from the last few years that some strains of Klebsiella, Enterobacter and Citrobacter had been isolated from stools and the intestinal content of both children and adults in several epidemiological studies of acute and chronic disturbances (Twedt and Boutin, 1979). 
Certain numbers of Citrobacter had been suspected to cause enteric infection (Cruickshank et al., 1975), while Citrobacter freundii had been found among urinary and other pyogenic infections in humans (Mackie and MacCarteny, 1962).

The results tabulated in Table 9 revealed that $(18 \%)$ of examined natural yoghurt samples were contaminated by staphylococci, the level of contamination was ranged from $2.0 \times 10^{2}$ to $4.0 \times 10^{5}$ with a mean value of $1.7 \times 10^{4}$, while $(16 \%)$ out of examined fruit yoghurt samples were ranged from $4.0 \times 10^{2}$ to $7.0 \times 10^{3}$ with a mean value of $5.2 \times 10^{2}$. Only $(8.0 \%)$ of examined flavored yoghurt samples were contaminated by staphylococci, as the level of contamination was ranged from $2.0 \mathrm{x} 10^{2}$ to $3.0 \mathrm{x} 10^{3}$ with an average of $1.6 \times 10^{3}$.

Relatively similar results were obtained by El-Shinawy (1987), AlAshmawy et al. (1991); Ali et al. (2004), while higher values were reported by El-Badry (1998).

The results presented in Table 10 showed coagulase production of isolated staphylococci strains in examined yoghurt samples $12 \%$ of natural yoghurt samples were strongly coagulase positive and $4 \%$ were positive coagulase and $2 \%$ were weakly positive coagulase, while in examined fruit yoghurt samples $12 \%$ and $4 \%$ were strongly positive and positive coagulase, respectively, but in case of flavored yoghurt samples $4 \%$ were strongly coagulase positive and the same percentages were weakly positive coagulase.

According to identification of isolated staphylococci Table 11 showed that Staphylococcus aureus was detected in 6(12\%) out of examined natural yoghurt samples, while $(6 \%)$ out of them were contaminated by Staphylococcus epidermidis, while in case of fruit and flavored yoghurt samples (12\% and $4 \%$ ) and (4\% and 4\%) were contaminated by Staphylococcus aureus and Staphylococcus epidermidis, respectively.

These findings were inagreement with that reported by Saleem et al. (1989) and coincided with those obtained by El-Bessery (2001) who found that all examined yoghurt samples were free from Staphylococcus aureus.

Human being normally harbours Staphylococcus aureus as the main reservoir is the nasal cavity and from this source, organisms find their way to skin and into wounds either directly or indirectly. In addition, Staphylococcus aureus may be found in eyes, throat and intestinal tract. Therefore, nasal carriers and individuals whose hands and arms were infected with boils and carbuncles are dangerous sources of foodpoisoning (Jay, 1992). 
Staphylococcus aureus is by far the most important human pathogen among the staphylococci. Under certain circumstances, Staph.aureus may cause a variety of infectious diseases, ranging from relatively benign skin infectious diseases to life threating systemic illness.

Enterotoxins producing staphylococci are the leading cause of food borne illness throughout the world. Staph. aureus posses a public health hazard due to production of thermostable enterotoxins that is responsible for food-poisoning. The growth of Staphylococcus aureus in food is a potential public health hazard, since many strains of Staphylococcus aureus produce enterotoxins which cause food-poisoning if ingested (Pazakova et al., 1997).

Although Staph. aureus, the coagulase positive is the most dangerous, but nowadays coagulase negative staphylococci have been recognized as important agents of human disease which include nasocomital and community-acquired urinary infections, bacteremia in compromised hosts, osteomyleitis and post-surgical infections.

Salmonella failed to be detected in all examined samples. The findings substantiated what had been reported by Aboul-khier et al. (1985); Amer et al. (1985); Rodriguez et al. (1990); Mufandaedza et al. (2006); Abd El-Fatah (2007). On the contrary Wang et al. (2004) could detect Salmonella in (3\%) out of examined yoghurt samples. These results may be attributed to that yoghurt culture had an inhibitory effect on salmonellae within the range of (92.5-99.8\%) (Lukasova et al., 1990).

The results recorded in Table 12 revealed that yersinia failed to be isolated from all examined natural and flavored yoghurt samples while $4(16 \%)$ out of 25 examined fruit yoghurt samples were contaminated with yersinia.

Table 13 showed that the isolated strains of Yersinia spp. were Yersinia pseudotuberculosis, $Y$. intermedia and $Y$. kristensenii in percentages of $8 \%, 4 \%$ and $4 \%$ of examined fruit yoghurt samples respectively. Yersinia enterocolitica failed to be detected in all examined natural, flavored and fruit yoghurt samples. Y. enterocolitica could be isolated by El-Prince and Sabreen (1998); El-Barbary (1999), but it failed to be detected by El-Kholy (1992). Umoh et al. (1984) could detect $Y$. enterocolitica in $2 \%$ out of examined yoghurt samples. This bacterium could contaminate yoghurt through raw milk used without sufficient heating or through contaminated equipment used for its production.

$Y$. enterocolitica has the distinction of surviving and multiplying in food held at refrigeration temperature, therefore milk and its products contaminated initially with even low level of this bacterium may serve not only as a vehicle, but also as a medium for its proliferation (Stern et al., 
1980). Milk and its products had been incriminated in several outbreaks of yersiniosis due to the psychrotrophic nature of Y. enterocolitica which was accompanied by increasing use of refrigeration in food preservation. A highly publicized food associated outbreak of yersiniosis among school children occurred in Oneida, New York, due to consumption of contaminated chocolate milk (Black et al., 1978).

Table 14 showed that the relation between acidity and isolated microorganisms. PH of the yoghurt prevents growth of coliform and act as inhibitor factors of the isolated microorganisms. These findings substantiated what had been reported by Mohammed and Younis (1990); Pesic (1991); Altaf et al. (1995); Hsin and Chou (2001); Mufandaedza et al. (2006).

From the previously mentioned date, we observed that efficient heat-treatment of milk used in manufacture of yoghurt caused a pronounced reduction in the bacterial load of yoghurt and in turn, keeping quality were usually improved and the shelf-life may be expanded to twenty one days of storage periods (Dagher and Ali, 1985; Mohanan et al., 1985). Although, plastic cups were not satisfactory and may be responsible for poor quality of yoghurt and its postpasteurization contamination (Saudi et al., 1989).

\section{CONCLUSION}

The assessment of the results obtained allow to conclude that most of fermented milk in Sharkia Governorate don't satisfy the consumer's demand in obtaining such products in good sanitary condition and retaining as far as possible their nutritive value. Information given by the results of bacteriological examination reported here-in points out that the sanitary measures adopted during production and handling of this product is neglected in most cases as coliforms existed in some samples of yoghurt which are supposed to be heat treated before being manufactured.

\section{REFERENCES}

Abd El-Fatah, E.N. (2007): Sanitary studies on fermented milks marketed at Zagazig Markets. M.V.Sc. Thesis, Fac. Vet. Med. Zag. Univ., Egypt.

Abou-Donia, S.A.; Sirry, I.; Nofal, A.A. and Rashed, M.A. (1975): Identification of certain microbial isolates in zabady in Alexandria J. of Agri. Res., 23(3): 425. 
Aboul-Khire, F.A.; El-Bassiony, T. and El-Rab, H.G. (1985): Enterobacteriaceae in some milk products in Sohag city. Assiut Vet. Med. J., 1(28): 81-85.

Ahmed, A.M. (1989): Prevalence and survival of enteropathogenic Escherichia coli (EEC) in yoghurt. Assuit Vet. Med. J., 8 (41). Al-Ashmawy, A.M.; El-Sayed, M.; Amer, I.H. and Mansour, M.A. (1991): Hygienic status of plain yoghurt (yoplait). Zag. Vet. Med. J., 19 (3): 639-645.

Al-Hadethi, H.A.; Hammed, D.A. and Al-Kananny, E.K. (1992): Incidence of coliform bacteria in milk products in Mosul city. Iraqi. J. of Vet. Sci., 5 (2): 151-158.

Ali, M.M.; Nahed, M.; Wahba; S. and Farag, A. (2004): Microbiological evaluation of Assuit market yoghurt through the shelf life time in refrigerator. Assuit Vet. Med. J., 50 (101):64-74.

Altaf, A.; Serajuddaula, S.; Saleem, H. and Jafarey, N.A. (1995): Is yoghurt a source of gasteroenteritis? J. of Pakistan Medical Assoc., 45 (100): 283.

Amer, I.H.; Shelaih, M.A.; Morgan, S.D. and Sallam, S. (1985): Incidence of enterobacteriaceae in laban raieb. Zag. Vet. Med. J., 12 (2): 438-445.

"A.P.H.A." American Public Health Association (1992): Standard methods for the examination of dairy product. $16^{\text {th }}$ Ed., New York.

Anonymous, S.M. (1977): Yersinia enterocolitica outbreaks, New York Morbid. Mortal. Weekly Rep., 26: 7.

Ayoub, M.A. (1986): Studies on the sanitary condition of some dairy products in Zagazig markets. M.V.Sc. Fac. Vet. Med. Zag. Univ., Egypt.

Ayoub, M.A. (1991): Incidence of pathogenic serotypes of E.coli in fermented dairy products. Ph. D. Thesis Fac. Vet. Med. Zag. Univ., Egypt.

Bahout, A.A. and El-Shawaf, A.M. (1999): Evaluation of some chemical and bacteriological aspects of commercial yoghurt in Sharkia province. J. Vet. Med. Res., 1 (1): 1-9.

Black, R.E.; Jackson, R.J.; Tsai, T.; Medvesky, M.; Shayegani, M.; Feeley, T.C.; Macleod, K.L.E. and Wakelee, A.M. (1978): Epidemic Yersinia enterocolitica infection due to contaminated chocolate milk. New Engl. J. Med., 12: 76-79.

Brazal Garcia, T.; Ruiz, A.R. and Espejo, D.M. (1986): Microbiological quality of natural and flavored yoghurts consumed in Alicante 
Province. Alimentaria, No. 177, 39-42. Dairy Sci. Abst., 49 (10): 62-65.

Cowan, S.T. and Steel, K.J. (1974): Manual for identification for medical bacteria. $2^{\text {nd }}$ Cambrige Uni. Press, England.

Cruickshank, R.; Duguide, J.P.; Marmion, B.P. and Swain, R.H.A. (1975): Medical Microbiology. 12 $2^{\text {th }}$ Ed., Vol. II, Churchill Livingstone Ltd., Edinburgh, London and New York.

Dagher, S. and Ali, A. (1985): Effects of pasteurization, centrifugation and additives quality of concentrated yoghurt (labneh) .J. of Food Prot., 48.

El-Badry, S.A. (1998): Sanitary quality of yoghurt. M.V.Sc. Thesis Fac. Vet. Med. Zag. Univ., Egypt.

El-Barbary, M.M. (1999): Occurrence of enteric microorganisms in some dairy products in Sharkia Governorate. M.V.Sc. Thesis Fac. Vet. Med. Zag. Univ., Egypt.

El-Bessery, M.M.A. (2001): Microbiological quality of market fermented milks in Assuit city. M.V. Sc. Thesis, Fac. Vet. Med. Assuit Univ., Egypt.

El-Kholy, A.M. (1992): Occurrence of Yersinia enterocolitica in ice cream and yoghurt .Assiut, Vet. Med. J., 27 (54): 108-113.

El-Prince, E. and Sabreen, M. S. (1998): Some studies on Ref. Yersinia enterocolitica in milk and some dairy products. $8^{\text {th }}$ Sci. Con. Fac. Vet. Med. Assuit Univ., Egypt, 15-17 Nov., 22-32.

El-Shinawy, S.H. (1987): Microbiological studies on fermented milks. Ph. D. Thesis Fac. Vet. Med. Zag. Univi., Egypt.

Farid, A.F.; Kaldas, Y.T.; Henin, A.Y. and Saad, M.K. (1992): Microbiological quality of yoghurt produced at Minia, Middle Egypt. In proceeding of the $3^{\text {rd }}$ world congress on food born infections and intoxication, Berlin, Germany, 16-19 June 1992 Vol. I. Dairy Sci. Abst., 57 (1): 224.

FDA (1998): Food and Drug Administration. Bacteriological analytical manual 8th Edition, AOAC. Interational, Gaithersburg, USA.

Goel, M.C.; Kulshrestna, D.C.; Marth, E.H.; Francis, D.W.; Bradshaw, J.G. and Read, R.B.J. (1971): Fate of coliforms in yoghurt. J. of Milk Food Technol., 34 (1): 54-58.

Hsin, Y. and Chou, C. (2001): Acid adaptation and temperature effect on the survival of E.coli O157:H7 in acidic fruit juice and lactic fermented milk product. Int. J. of Food Microbiol., 70 (1-2): 189-95. 
ICMSF "International Committee on Microbiological Specifications for Foods" (1986): Microorganisms in food sampling for microbiological analysis, principle and specific application. Blackwell Scientific Oxford.

Jay, J.M. (1992): Modern Food Microbiology. $4^{\text {th }}$ Ed. Van Nostrand, Reinhold, New york.

Krieg, N.R. and Holt, J.N. (1984): Bergeys Manual of Systemic Bacteriology. Vol. 1 Wilkins Company, Baltin, M.D.21202, U.S.A.

Lukasova, J.; Radova, P.; Sojkova, M. and Krystofova, J. (1990): The effect of milk cultures on the survival of Salmonellae in milk. Vet. Med. J., 35 (2):81-86.

Mackie, T.J. and MacCarteny, J.E. (1962): Handbook of Practical Bacteriology, $10^{\text {th }}$ Ed.E85. Livingstone Ltd., London.

Mansour, M.A.; Bahout, A.A.; Al-Abeedy, A.A. and El-Barbary, M.M. (1999): Occurrence of some enteric microorganisms in some dairy products in Sharkia Governorate. Beni Suef Vet. Med. J., 9 (3): 387-398.

Mohammed, F.O. and Younis, Y.A. (1990): Effects of yoghurt cultures on some pathogenic microorganisms in fermented milks. Egyptian J. of Dairy Sci., 18: 369-375.

Mohanan, K.P.; Shanker, P.A. and Alxminarayana, H. (1985): Microflora of Dahi prepared under household conditions of Banalore. J. Fd. Sci. and Technol. India 21 (1): 45-46 Dairy Sci. Abst., 47, 107.

Moustafa, A. H. M. (1988): Occurrence and significance of enterococci in milk and some dairy products. M.V.Sc Thesis Fac. of Vet. Med. Zag. Univ., Egypt.

Moustafa, M.K.; Ahmed, A.A.H. and Abdel-Hakiem, E.H. (1988): Sanitary condition of commercially available yoghurt in Assuit city. Assuit Vet. Med. J., 20 (39): 99-103.

Moustafa, M.K.; Ahmed, A.A.H. and Marth, E.H. (1983): Occurrence of Yersinia enterocolitica in raw and pasteurized milk. J. of Food. Prot., 46: 276-278.

Mufandaedza, J.; Viljoen, B.C.; Feresu, S.B. and Gadaga, T.H. (2006): Antimicrobial properties of lactic acid bacteria. LAB cultures isolated from traditional fermented milk against pathogenic Escherishia coli and Salmonella enteritidis strains. Int. J. of Food Microbiol.

Newsome, R.L. (1988): Staph. aureus. Food Technol., 42 (4):149. 
Odinot, P.T.; Meis, J.F.G.M.; Van Den Hurk, P.J.J.S.; HoogkampKorstanje, J.A.A. and Melchers, W.J.G. (1995): PCR-based characterization of Yersinia enterocolitica: Comparsion with biotyping and sero typing .Epidemiol. Infect., 115: 269-277.

Pazakova, J.; Turek, P. and Laciakova, A. (1997): The survival of Staphylococcus aureus during the fermentation and storage of yoghurt. J. of Appl. Microbiol., 82 (5): 659-662.

Pesic, D. (1991): Microbiological quality of yoghurt. Hrana-Ishrana, 32 (4): 193-195.

Pintor, D.M.; Gonzalez, P.A and Alvarez, M. (1989): Development of microorganisms of hygienic interest in commercial yoghurt. Alimentaria, 26 (205): 51-55.

Potter, N.A. and Hotchkiss, J.H. (1995): Food Science. $5^{\text {th }}$ edition, Chapman and Hall. London, England.

Prakash, S. and Kulkarni, P.R. (1986): Antimicrobial activity of Dahi, Indian. J. of Dairy Sci., 39-97.

Robert, M.T. and Brenda, K.B. (1979): Potential public significance of non-E.coli Coliforms in food, J. Food Prot., 42 (2): 161-163.

Robert, T.A.; Baird parker, A.C. and Tompkin, R.P. (1996): Microorganisms in food $1^{\text {st }}$ edition. Chapman and Hall, London.

Robinson, R.K. and Khan, P. (1978): Plant Foods for Man, 2: 113.

Rodriguez, A.C.; Pintor, D.; Gonzalez, P.A.; Alvarez, H.R. and Hardisson, D.T.A. (1990): Microorganisms of food hygiene interest in commercial yoghurt in the Canary Islands. Alimentaria, 212, 55-58. Dairy Sci. Abst., 57: 78-92.

Rubin, H.E. (1985): Protective effect of casein toward Salmonella typhimurium in acid. Milk J. Bacteriol., 58 (3): 251-255.

Saad, N.M.; Moustafa, M.K. and Ahmed, A.H. (1987): Microbiological quality of yoghurt produced in Assuit city. Assuit Vet. Med. J., 19 (37): 87-91.

Saleem, M.; Zaka, U.R. and Rehman, A.M. (1989): Study on the microbiological status of different varieties of local food. Pakistan J. of Scientific and Industrial Res., 32 (2): 103-106.

Sangwan, K.P.S. (2008): Technology of Dairy Plant operation. Agrobios, India.

Saudi, A.M.; El-Essawy, H.A. and Hafez, N.M. (1989): Aspects on the microbiological status of yoghurt plastic containers. Vet. Med. J. Giza, 37 (3): 397-406. 
Saudi, A.S.; Morgan, S.D.; Hafez, R.S. and El-Essawy, H.A. (1988): Aspects on the microbial status in fruit yoghurt. Zag. Vet. J., 16 (2): 130-140.

Shahani, Y.A.; Sadek, G.; Naguib, K. and Sabbour, M. (1974): The viability of salmonella typhimurium in Zabady. Egypt. J. Microbiol., 7(1): 97-101.

Stern, N.J.; Pierson, M.D. and Kotula, A.W. (1980): Growth and competitive nature of Yersinia enterocolitica in whole milk. J. of Food Sci., 45: 972-974.

Steven, D.G. (1969): "Yoghurt as a food and in the prevention and treatment of disease". Vitalstoffezivilisation skraankheiten. 14(2): 66-69.

Tacket, C.O.; Narain, J.P.; Sattin, R.; Lofgren, J.P.; Konigsberg, C.; Rausa, A.; Davis, B.R. and Cohen, M.L. (1984): Amultistate outbreaks of infection caused by Yersinia enterocolitica transmitted by pasteurized milk. J. Amer. Public Health Assoc., 251-483.

Tamime, A.R. and Robinson, R.K. (1985): Yoghurt Science and Technology. Copyright Pergamon Press. Ltd.

Twedt, R.M. and Boutin, B.K. (1979): Potential public health significance of non E.coli Coliforms in food. J. of Food Prot., 42 (2): 161-163.

Umoh, V. J.; Dangana, A. and Umoh, J.U. (1984): Isolation of Yersinia enterocolitica from milk and milk products in Zaria Nigeria. Int. J. Zoon., 11: 223-228.

Varnam, A.H. and Evans, M.G. (1991): Food borne pathogens, An illustrated test. Published by Wolf Publishing Ltd., England.

Wang, M.; Ran, Z. and Liz, W. (2004): Study on national active monitoring for food borne pathogens and antimicrobial resistance in China 2001. Wei Sheng Yan Jiu, 33 (1): 49-54.

Wernozy Rozand, C.; La Peyrre, C.; Brun, Y. and Fleurette, J. (1996): Enterotoxin production by coagulase negative Staph. Isolated from goat's milk and cheese. Int. J. Food Microbiol., 30: 271-28. 